\title{
Patients' satisfaction with the care provided by nurse practitioners in primary care settings of a remote region of Canada: A cross-sectional study
}

\author{
Safa Regragui ${ }^{1}$, Frances Gallagher ${ }^{2}$, Manon Lacroix ${ }^{1}$, Guylaine Leblond ${ }^{1}$, Sylvie Cardinal ${ }^{1}$, Lyne Fecteau ${ }^{1}$, Anaïs \\ Lacasse*1 $^{*}$ \\ ${ }^{1}$ Département des sciences de la santé, Université du Québec en Abitibi-Témiscamingue, Rouyn-Noranda, Québec, Canada \\ ${ }^{2}$ École des sciences infirmières, Faculté de médecine et des sciences de la santé, Université de Sherbrooke, Sherbrooke, Québec, \\ Canada
}

Received: May 11, 2019

DOI: $10.5430 /$ cns.v7n3p79
Accepted: July 8, 2019

Online Published: July 11, 2019

\begin{abstract}
Objective: A cross-sectional correlational design was used to describe patients' satisfaction with primary healthcare nurse practitioners and identify factors associated with their satisfaction regarding the services received in a remote region of Quebec, Canada.

Methods: Patients who received care from eight primary healthcare nurse practitioners were asked to complete a self-administered questionnaire. STROBE checklist was adhered.

Results: A total of 574 patients were recruited (participation rate: 76.6\%). Patients were very satisfied with the healthcare services received, relationship with the practitioner, information received, duration of the consultation, and the overall consultation (89.6\%-93.3\%). The only variable associated with a higher likelihood of being very satisfied with the overall consultation was a longer duration of the consultation (adjusted OR: 1.029; CI: 1.005-1.054; $p=.018$ ).

Conclusions: The high level of patients' satisfaction and trust with healthcare nurse practitioners is a potential contributing factor to past and future success of their integration in primary healthcare services.
\end{abstract}

Key Words: Nurse practitioner, Patients's satisfaction, Primary healthcare, Advance nurse practice

\section{INTRODUCTION}

Primary healthcare nurse practitioners (PHCNPs) are "registered nurses with additional educational preparation and experience who possess and demonstrate the competencies to autonomously diagnose, order and interpret diagnostic tests, prescribe pharmaceuticals and perform specific procedures within their legislated scope of practice". ${ }^{[1]}$ The development of PHCNPs' role has been established in Canada and in the
United States in the late 60 s in order to provide primary care to residents of rural or remote regions for whom healthcare services have traditionally been less accessible. ${ }^{[2-7]}$ Other countries such as the United Kingdom or Australia have followed ${ }^{[8,9]}$ and PHCNPs' role is now well established worldwide. ${ }^{[10-12]}$ In the province of Quebec (Canada), PHCNPs' contribution has been more recent and their integration has significantly grown in the past ten years since the implemen-

\footnotetext{
*Correspondence: Anaïs Lacasse; Email: lacassea@uqat.ca; Address: Département des sciences de la santé, Université du Québec en, AbitibiTémiscamingue, 445, boul. de l'Université, Rouyn-Noranda (Qc), J9X 5E4, Québec, Canada.
} 
tation of the training programs in 2007 and their integration in primary care settings in 2009. ${ }^{[13]}$ Compared to other Canadian provinces or countries, the province of Quebec is several years behind. In fact, even PHCNPs holding a diploma issued by an educational institution located outside Quebec could not receive a Quebec PHCNPs licence from the provincial nurses order before 2008. Factors such as the late implementation of PHCNPs, their narrower scope of practice and medical power have greatly influenced the acceptance of this new professional role. ${ }^{[14-17]}$

Patients' satisfaction with the care received is an important and commonly used indicator for measuring the quality of healthcare and for identifying areas for improvement. ${ }^{[18,19]}$ It is also an important outcome to measure when introducing a new professional role in the delivery of care. ${ }^{[20]}$ Of importance to remember is that patients' satisfaction is influenced by many factors, including communication between the practitioner and the patient, duration of consultation, waiting time, and socioeconomic status. ${ }^{[21]}$ These variables may have an impact on the perceived quality of the care provided and hence influence the subsequent assessment of satisfaction.

Although several recent studies in Canada ${ }^{[21-23]}$ and elsewhere ${ }^{[10,12,20,24-26]}$ have looked at patients' satisfaction with PHCNPs' care, no study has been conducted in the province of Quebec, and especially none in the context of its remote regions. Given the importance of PHCNPs' role in providing care to rural and remote populations ${ }^{[24,27-30]}$ and since patients' satisfaction and trust can contribute to the successful integration of PHCNPs in healthcare settings, ${ }^{[31-33]}$ new data is desirable. The aims of this study were to describe patients' satisfaction with PHCNPs in a remote region of the province of Quebec, and identify factors influencing patients' satisfaction regarding the services they received.

\section{MethodS}

\subsection{Study design and setting}

A cross-sectional correlational design was used in a convenience sample of patients who received care from a PHCNP practicing in a remote region of the province of Quebec (Canada). Healthcare settings (family medicine groups, family medicine units, community health centres and private clinics) were located in five municipalities (two urban and three rural). The specific region under study is a vast and remote region with a population of approximately 147,982 inhabitants and a land area of $57,349 \mathrm{~km}^{2} \cdot{ }^{[34]}$ It is characterized by small urban areas and low density rural areas with over half of the population (58\%) residing in urban poles and $(42 \%)$ living in rural areas. ${ }^{[35]}$

\subsection{Procedure}

At the time of the study, eight PHCNPs were practicing in 10 different primary care settings of the remote region of interest (two of the eight PHCNPs worked in two different settings of practice). They all agreed to participate in the study. In each setting of practice, PHCNPs were asked to distribute 75 self-administered questionnaires to their patients in order of arrival. Questionnaires were anonymous to reduce the possibility of social desirability bias. A total of 750 questionnaires were thus distributed (see Figure 1) and each patient could participate only once. Questionnaires were handed out to patients by PHCNPs at the end of the medical consultation. Patients were then asked to fill it out in the waiting room and to place it in a sealed box located at the reception of the clinic. The box containing questionnaires filled-out by patients was only accessible to the research team (not PHCNPs).

\subsection{Data collection and variables}

Data were collected in 2014. The questionnaire started with a cover letter and was no longer than 3 pages in length. To maximize face and content validity, the questionnaire was developed in collaboration with two registered nurses and one PHCNP who were not targeted as potential study participants. They also reviewed the final version of the questionnaire. It was then pre-tested among patients of various socioeconomic status $(n=4)$.

The questionnaire, developed for the present study, started with a brief introductory text about the role of the healthcare professional patients met that day, i.e., the PHCNP. Then, patients were asked the reason for the consultation (open-ended question), if it was the first time they met a PHCNP (yes/no), the length of the consultation (in minutes), and if they knew the role of a PHCNP before the consultation (yes/no). Satisfaction with the PHCNP consultation was assessed using five questions (4-point Likert scales: very satisfied, satisfied, dissatisfied, very dissatisfied) and focused on five dimensions of satisfaction : 1) Healthcare received, 2) Relationship with the PHCNP (listening, respect, understanding, dedication, etc.), 3) Information received about prevention, treatment or care for the patient's condition (or condition of his/her child), 4) Duration of the meeting with the PHCNP, and 5) Overall satisfaction with the day's medical consultation. These constructs were previously identified as important for the adequate measurement of satisfaction with nurse practitioners. ${ }^{[36,37]}$ Our five satisfaction questions were intended to be analyzed separately and were not used to compute a total score. The questionnaire also surveyed patients agreement (yes/no) with the following statements: 1) "The care I received today from the PHCNP was up to my expectations", 2) "Today's meeting with the PHCNP has allowed me to 
access healthcare more quickly", 3) "My meeting today with the PHCNP allowed me to avoid going to the emergency room", 4) "I trust the PHCNP I met today to take care of my health (or the health of my child)", 5) "I would recommend my PHCNP to a family member or a friend". Finally, other collected variables included distance between patients' residence and the clinic (in km), age, sex, employment status, education level, annual family income, and self-perceived health (5-point Likert scale: excellent, very good, good, fair, poor).

\subsection{Ethical considerations}

Participation was voluntary and completion of the questionnaire indicated willingness to participate in the study. Approval for the research was obtained from the Universite du Québec en Abitibi-Témiscamingue Ethics Committee and written approval was obtained from the directors of each healthcare setting.

\subsection{Data analysis}

The data collected was subjected to descriptive statistics according to the type and the distribution of variables, i.e., means, medians, standard deviations $(S D)$, frequencies and proportions (\%). Satisfaction levels were compared between specific subgroups of patients (e.g., those who had a consultation with a PHCNP before vs first timers) using chi-squared tests. Factors associated with patients' overall satisfaction with the PHCNP consultation (being very satisfied with the consultation yes/no) were identified through univariate and multivariate logistic regression models. In the multivariate model, all potential predictors were entered simultaneously. Results are presented as crude and adjusted odds ratios (OR), their respective $95 \%$ confidence intervals (95\%CI), and $p$-values. The significance level was set at .05. All analyses were conducted with IBM SPSS Statistics, version 22.0 (Armonk, NY: IBM Corp.).

\section{Results}

Figure 1 shows that a total of 574 patients completed the self-administered questionnaire which yielded an overall participation rate of $76.6 \%$ (range across study sites: $61.4 \%$ $96.0 \%$ ). Participation rates and characteristics of the different healthcare settings could not be analyzed because study sites were anonymized in the analysis (for ethical reasons).

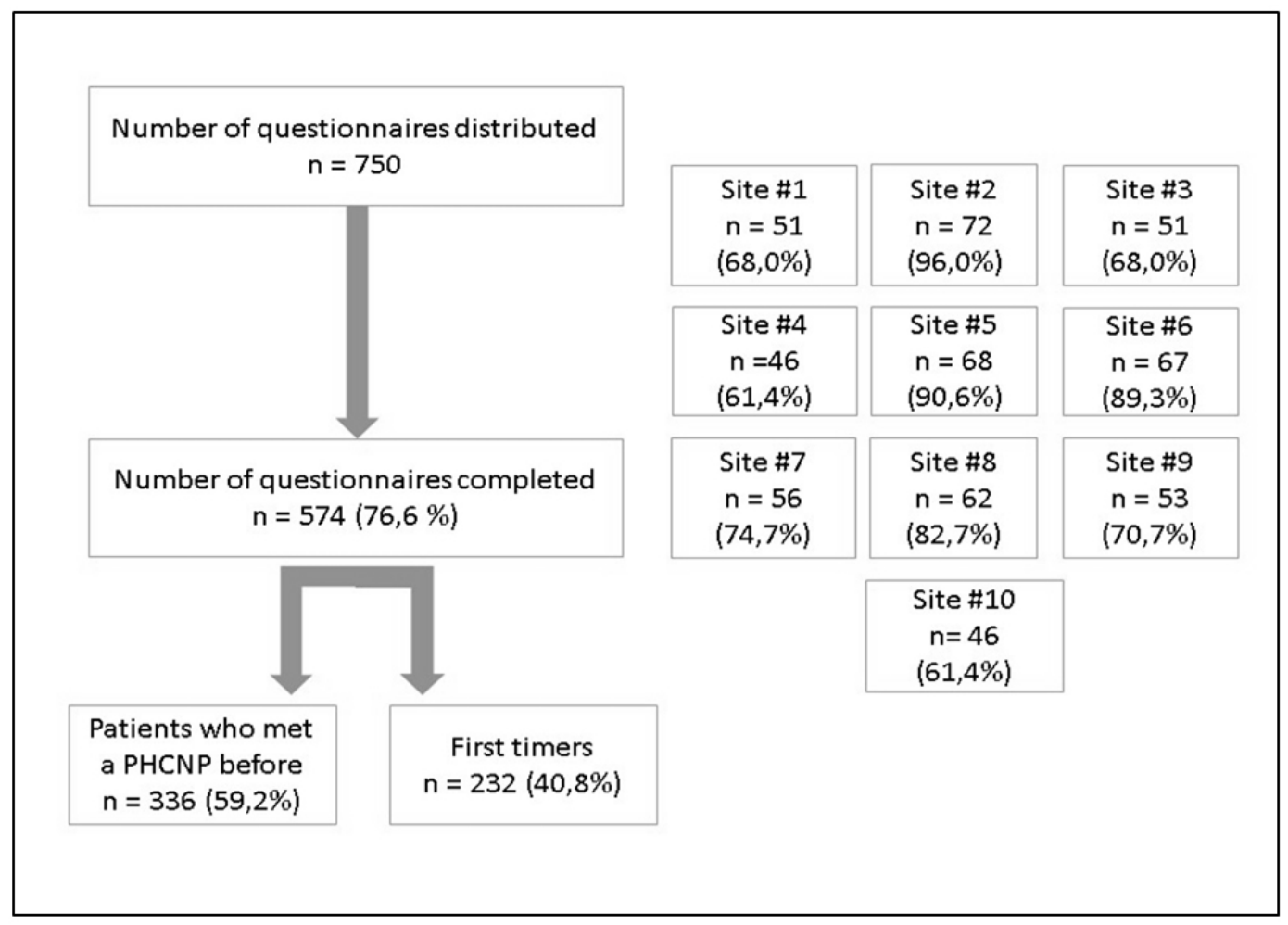

Figure 1. Study flow diagram

About forty percent of patients reported consulting a PHCNP for the first time. Demographics and characteristics of the study population are presented (see Table 1). Participants' mean age was 50.7 years (SD: 17.5 ) and $77.9 \%$ were women. A majority of patients met the PHCNP for an annual/periodic medical examination or drug prescription (55.7\%) and $77.9 \%$ 
knew the role of a PHCNP before the day's consultation.

Table 1. Characteristics of the study sample

\begin{tabular}{|c|c|}
\hline Characteristics & $n=574$ \\
\hline \multicolumn{2}{|l|}{ Sociodemographic } \\
\hline - Age (years) - mean (SD) & $50.66(17.49)$ \\
\hline - Median & 53 \\
\hline - Min & 3 \\
\hline - $\operatorname{Max}$ & 89 \\
\hline \multicolumn{2}{|l|}{$\operatorname{Sex}-\mathbf{n}(\%)$} \\
\hline - Males & $197(22.1)$ \\
\hline - Females & $371(77.9)$ \\
\hline \multicolumn{2}{|l|}{ Employment status - n (\%) } \\
\hline - Full-time job & $267(47.8)$ \\
\hline - Part-time job & $61(10.9)$ \\
\hline - Retired & $156(28.0)$ \\
\hline - Unemployed & $28(5.0)$ \\
\hline - Others & $46(8.2)$ \\
\hline \multicolumn{2}{|l|}{ Education level - n (\%) } \\
\hline - Elementary & $51(9.2)$ \\
\hline - High school & $205(36.9)$ \\
\hline - Diploma in vocational studies & $113(20.4)$ \\
\hline - College/CÉGEP & $94(16.9)$ \\
\hline - University & $92(16.6)$ \\
\hline \multicolumn{2}{|l|}{ Annual family income $-\mathbf{n}(\%)$} \\
\hline - Less than $\$ 20000$ & $102(19.3)$ \\
\hline - $\$ 20000-\$ 39999$ & $145(27.5)$ \\
\hline - $\$ 40000-\$ 59999$ & $88(16.7)$ \\
\hline - $\$ 60000$ - \$79999 & $67(12.7)$ \\
\hline - Over $\$ 80000$ & $126(23.9)$ \\
\hline \multicolumn{2}{|l|}{ Health and consultation-related variables } \\
\hline \multicolumn{2}{|l|}{ Reason for the consultation $-\mathbf{n}(\%)$} \\
\hline - Annual/periodic medical examination or drug prescription & $320(55.7)$ \\
\hline - Acute or chronic pain & $51(8.9)$ \\
\hline - Infections (e.g., urinary, flu, sinusitis, otitis) & $43(7.5)$ \\
\hline $\begin{array}{l}\text { - Gynecology (e.g., Pap test, intrauterine contraceptive } \\
\text { device) }\end{array}$ & $25(4.4)$ \\
\hline - Diabetes & $24(4.2)$ \\
\hline - Cardiovascular complaints & $21(3.7)$ \\
\hline - Dermatological problems & $21(3.7)$ \\
\hline - Mental Health & $20(3.5)$ \\
\hline - Other ${ }^{* *}$ & $43(7.5)$ \\
\hline $\begin{array}{l}\text { Length of the consultation with the PHCNP (min) - mean } \\
\text { (SD) }\end{array}$ & $33.07(15.85)$ \\
\hline - Median & 30 \\
\hline - Min & 2 \\
\hline - $\operatorname{Max}$ & 90 \\
\hline \multicolumn{2}{|l|}{ Knew the role of a PHCNP before the consultation $-\mathrm{n}(\%)$} \\
\hline - Yes & 445 (77.9) \\
\hline - No & $126(22.1)$ \\
\hline $\begin{array}{l}\text { Distance between patient's residence and the clinic }(\mathbf{k m}) \text { - } \\
\text { mean }(S D)\end{array}$ & $14.59(28.46)$ \\
\hline - Median & 5 \\
\hline - Min & 0 \\
\hline - $\operatorname{Max}$ & 500 \\
\hline \multicolumn{2}{|l|}{ Self-perceived health $-\mathbf{n}(\%)$} \\
\hline - Excellent & $52(9.3)$ \\
\hline - Very good & $217(38.8)$ \\
\hline - Good & $232(41.5)$ \\
\hline - Fair & $51(9.1)$ \\
\hline - Poor & (1.3) \\
\hline
\end{tabular}

Patients' satisfaction regarding the healthcare services received, relationship with the PHCNP, information received, duration of the meeting, and overall satisfaction with the day's medical consultation are presented (see Figure 2). For all these aspects, a large majority of patients were very satisfied with the PHCNP consultation (89.6\%-93.3\%). No statistically significant differences $(p<.05)$ were found between patients who consulted with a PHCNP before and first timers regarding the different satisfaction outcomes, except for satisfaction with the information received which was higher among patients who consulted a PHCNP before (very satisfied: $91.0 \%$ vs. $83.8 \%, p$.024). No statistically significant differences $(p<.05)$ were found between patients who met the PHCNP for an annual/periodic medical examination/drug prescription and patients who met the PHCNP for other reasons.

Figure 3 shows the proportion of patients who agreed with various statements about the PHCNP they met that day. Almost all patients $(92.8 \%-100 \%)$ reported that the care they received met their expectations, that meeting with the PHCNP has allowed them to access healthcare more quickly or to avoid going to the emergency room, that they trust the PHCNP to take care of their health, and that they would recommend the PHCNP to a family member or friend.

Table 2 shows the results of individual univariate analyses and the final multivariate model conducted in order to identify factors associated with patients' overall satisfaction with the consultation with a PHCNP. Controlling for sociodemographic, health and consultation-related variables, the only factor identified as being associated with a higher likelihood of reporting being very satisfied with the consultation was a longer duration of the consultation with the PHCNP which varied from patient to patient (adjusted OR: $1.03 ; p$.02). It should be noted that the duration of the consultation was substantially variable from one patient to another (mean: 33.1 minutes, $S D$ : 15.95, $\min : 2$, $\max : 90)$.

\section{Discussion}

Patients' satisfaction with PHCNPs has not been previously studied in the province of Quebec or in its remote and rural regions. The present cross-sectional investigation conducted with 574 patients who received care from a PHCNP practicing in a remote region of the province of Quebec suggests that patients with various sociodemographic profiles are satisfied with the care they receive from PHCNPs and show high levels of trust in their PHCNPs. The results also suggest that the duration of the consultation with the PHCNPs is the only significant predictor of patients' satisfaction. 


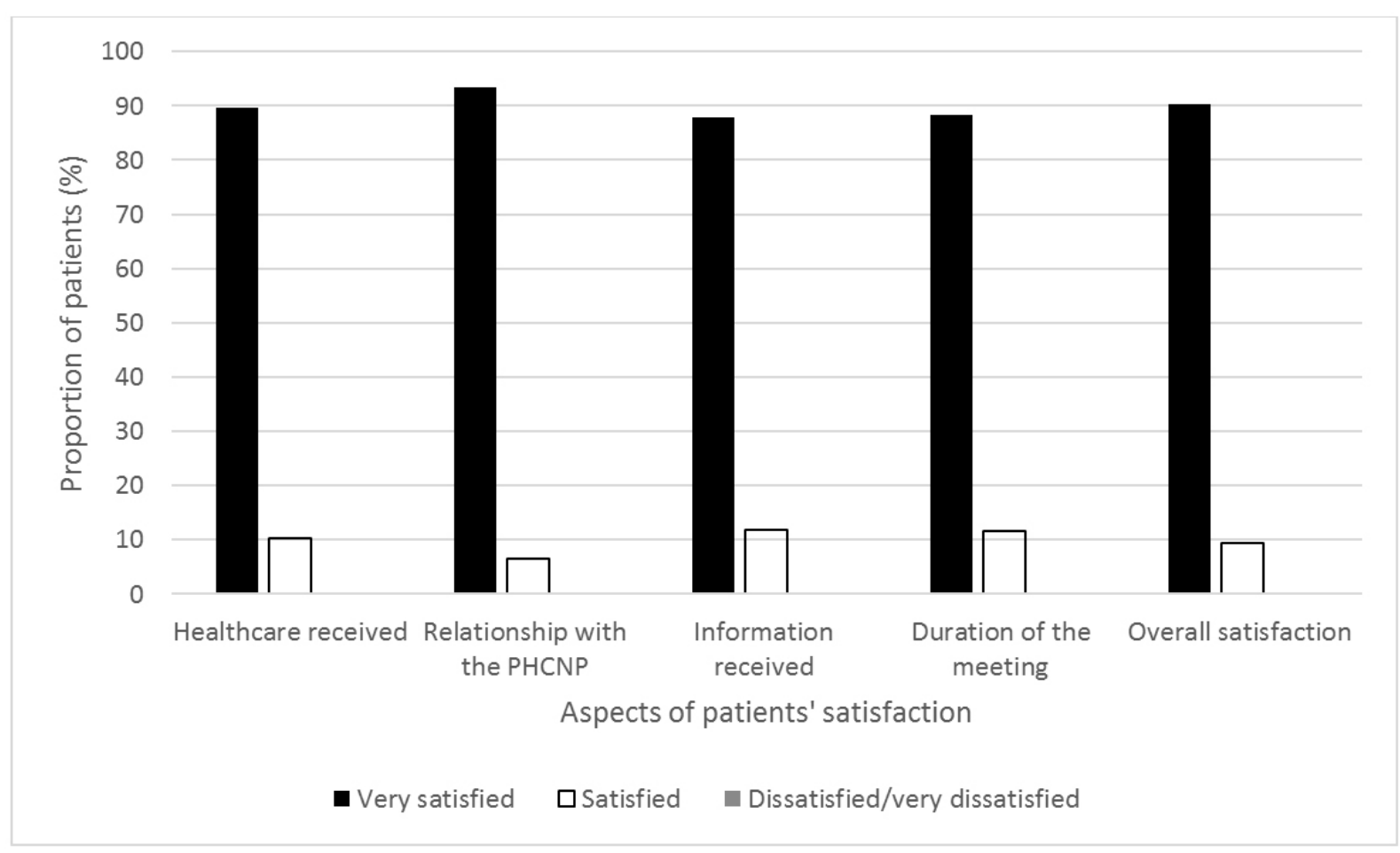

Figure 2. Satisfaction with the PHCNP consultation

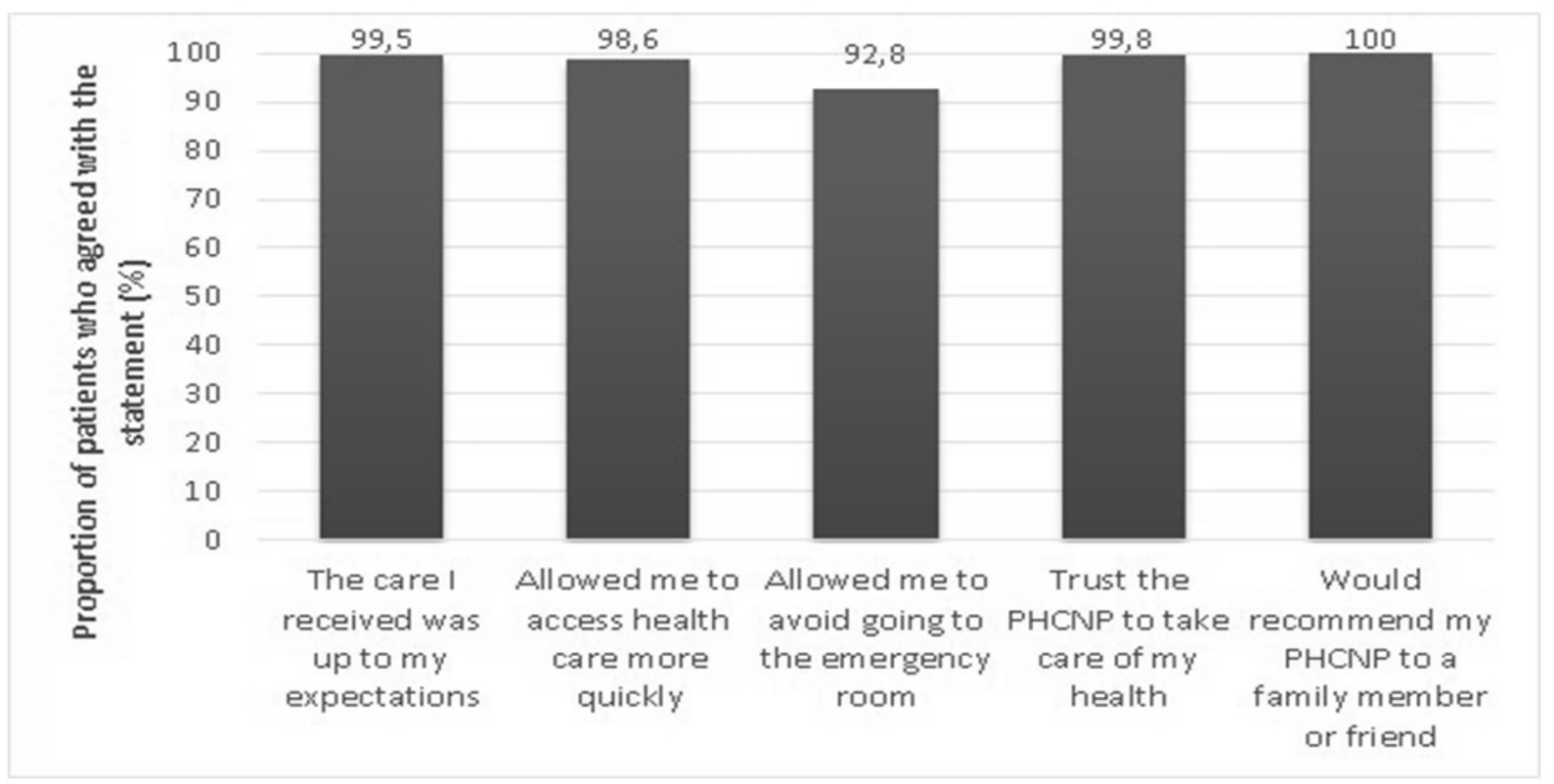

Figure 3. Agreement of patients towards statements about PHCNP (Primary healthcare nurse practitioner)

Patients' satisfaction with the care received is an important indicator commonly used to measure the quality of healthcare ${ }^{[18]}$ and has been identified as one of the factors facilitating the integration of PHCNPs into healthcare settings. ${ }^{[29,38-40]}$ Based on the present findings, the integration of PHCNPs resulted in high levels of patients' satisfaction with PHCNPs' care, which is in line with the current scientific literature. ${ }^{[38,41-43]}$ A recent study reported that $96 \%$ of patients rated the care they received from PHCNPs as excellent in terms of courtesy, respect, patience and responsiveness. ${ }^{[22]}$ It was also reported that patients appreciated the way PHCNPs provided individualized care and actively 
listened to them. ${ }^{[44]}$ In sum, there is evidence that the high tributing factor to the past and future success of PHCNPs' level of patients' satisfaction with PHCNPs' care is a con- integration in remote regions of the province of Quebec.

Table 2. Univariate and multivariate analysis of factors associated with higher satisfaction with the PHCNP consultation

\begin{tabular}{|c|c|c|c|c|c|c|}
\hline Characteristics & $\begin{array}{l}\text { Patients reporting } \\
\text { being very satisfied } \\
\text { with the consultation } \\
n=511\end{array}$ & $\begin{array}{l}\text { Others } \\
\mathbf{n}=55\end{array}$ & $\begin{array}{l}\text { Crude OR } \\
(95 \% \mathrm{CI})\end{array}$ & $p$-value & $\begin{array}{l}\text { Adjusted OR }{ }^{*} \\
(95 \% \mathrm{CI})\end{array}$ & $p$-value \\
\hline Age (year) - mean (SD) & $50.60(17.49)$ & $50.49(17.27)$ & $1.00(0,985-1,016)$ & .963 & $0.987(0.962-1.013)$ & .329 \\
\hline \multicolumn{7}{|l|}{$\operatorname{Sex}-\mathbf{n}(\%)$} \\
\hline - Males & $179(91.3)$ & $17(8,7)$ & - & & - & \\
\hline - Females & $331(89.7)$ & $38(10,3)$ & $0.827(0.454-1.508)$ & .536 & $0.570(0.271-1.200)$ & .139 \\
\hline \multicolumn{7}{|l|}{ Employment status - n (\%) } \\
\hline - Full-time job & $239(90.2)$ & $26(9.8)$ & - & - & - & - \\
\hline - Part-time job & $53(88.3)$ & $7(11.7)$ & $0.824(0.340-1.998)$ & .668 & $1.214(0.430-3.428)$ & .715 \\
\hline - Retired & $142(92.2)$ & $12(7.8)$ & $1.287(0.630-2.631)$ & .489 & $2.689(0.923-7.837)$ & .070 \\
\hline - Unemployed & $25(89.3)$ & $3(10.7)$ & $0.907(0.256-3.209)$ & .879 & $1.311(0.261-6.573)$ & .742 \\
\hline - Others & $40(87.0)$ & $6(13.0)$ & $0.725(0.281-1.873)$ & .507 & $0.585(0.204-1.675)$ & .318 \\
\hline \multicolumn{7}{|l|}{ Education level - $\mathbf{n}(\%)$} \\
\hline - Elementary & $42(84.0)$ & $8(16.0)$ & $0.371(0.121-1.137)$ & .083 & $0.472(0.113-1.977)$ & .304 \\
\hline - High school & $181(89.2)$ & $22(10.8)$ & $0.581(0.227-1.485)$ & .257 & $0.581(0.191-1.773)$ & .340 \\
\hline - Diploma in vocational studies & $104(92.9)$ & $8(7.1)$ & $0.918(0.306-2.747)$ & .878 & $1.415(0.394-5.072)$ & .595 \\
\hline - College/CEGEP & $84(89.4)$ & $10(10.6)$ & $0.593(0.206-1.705)$ & .332 & $0.636(0.196-2.060)$ & .450 \\
\hline - University & $85(93.4)$ & $6(6.6)$ & - & - & - & - \\
\hline \multicolumn{7}{|l|}{ Annual family income $-\mathbf{n}(\%)$} \\
\hline - Less than $\$ 20,000$ & $90(89.1)$ & $11(10.9)$ & $0.789(0.327-1.904)$ & .599 & $1.096(0.375-3.204)$ & .867 \\
\hline - $\$ 20,000-\$ 39,999$ & $128(88.9)$ & $16(11.1)$ & $0.772(0.344-1.732)$ & .530 & $0.867(0.353-2.127)$ & .755 \\
\hline - $\$ 40,000-\$ 59,999$ & $81(92.0)$ & $7(8.0)$ & $1.117(0.415-3.003)$ & .827 & $1.150(0.402-3.284)$ & .795 \\
\hline - $\$ 60,000-\$ 79,999$ & $62(95.4)$ & $3(4.6)$ & $1.994(0.536-7.417)$ & .303 & $3.211(0.664-15.535)$ & .147 \\
\hline - $\$ 80,000$ and over & $114(91.2)$ & $11(8.8)$ & - & - & - & - \\
\hline $\begin{array}{l}\text { Length of the consultation with } \\
\text { the PHCNP (min) - mean (SD) }\end{array}$ & $33.56(15.83)$ & $28.71(15.69)$ & $1.02(1.00-1.04)$ & .03 & $1.029(1.005-1.054)$ & .018 \\
\hline \multicolumn{7}{|l|}{$\begin{array}{l}\text { Knew the role of a PHCNP before } \\
\text { the consultation }-\mathrm{n}(\%)\end{array}$} \\
\hline - Yes & $400(90.7)$ & $41(9.3)$ & $0.85(0.48-1.50)$ & .58 & $1.517(0.743-3.100)$ & .253 \\
\hline - No & $110(88.7)$ & $14(11.3)$ & & & & \\
\hline $\begin{array}{l}\text { Distance between residence } \\
\text { location and the clinic }(\mathbf{k m}) \text { - } \\
\text { mean }(S D)\end{array}$ & $14.73(29.54)$ & $13.51(16.38)$ & $1.00(0.99-1.01)$ & .77 & $1.001(0.988-1.015)$ & .860 \\
\hline Self-perceived health - mean $(S D)$ & $1.51(0.83)$ & $1.81(0.83)$ & $0.652(0.466-0.911)$ & .012 & $0.686(0.454-1.036)$ & .073 \\
\hline
\end{tabular}

Note. * Accounting for the presence of missing data, the final multivariate model was achieved among 504 patients; PHCNP: Primary healthcare nurse practitioner; SD: Standard Deviation; 95\% CI: $95 \%$ confidence interval

Patients' trust in healthcare professionals, which is partly based on perceived competence, can affect their satisfaction and adherence to treatment. ${ }^{[45]}$ It was also demonstrated that the lack of trust in healthcare professionals could lead patients suffering from chronic conditions to be more inclined to ask for a second opinion or to use complementary and alternative medicines, which may in turn, result in a greater societal cost-of-illness. ${ }^{[45,46]}$ The fact that the present study showed that patients trusted PHCNPs to take care of their health, especially when forty percent of the present sample of patients reported meeting a PHCNP for the first time, is very positive considering the potential negative biopsychosocial consequences of distrust.

In line with the current literature, ${ }^{[10,12,20,47]}$ almost all patients reported that they would recommend the PHCNP they met to a family member or a friend, that the care they received was up to their expectations, and that meeting with the PHCNP has allowed them to access healthcare more quickly or to avoid going to the emergency room. Given that approximately 44,000 people in the remote region of interest did not have access to a family physician in 2013-2014, ${ }^{[48]}$ such perceptions on the part of patients reflect the extent to which PHCNPs' integration is important for the region, or even other worldwide areas with such primary care access challenges.

Controlling for potential confounders, the only factor identified as being associated with a higher likelihood of reporting being very satisfied with the consultation was a longer duration of the consultation with the PHCNP. Although the effect size is small ( $\mathrm{OR}=1.03$, maybe because of a lack of 
power), this finding is in line with other studies that have also shown that patients felt that PHCNPs spent enough time in each consultation, gave patients an opportunity to discuss their concerns, and took them seriously. ${ }^{[21,23]}$ In addition, it was found that the satisfaction of patients treated by PHCNPs was higher due to the fact that they spent a lot of time with them. ${ }^{[12,49,50]}$ Longer consultations allow PHCNPs to integrate health education information into the consultation and to understand, explore and address the underlying issues which are all key elements of patients' satisfaction. ${ }^{[21,31,51,52]}$ In summary, patients' satisfaction is not necessarily explained by the duration of the consultation as such, but by the fact that a longer consultation increases the quality of the dialogue. It is also believed that longer contact with healthcare professionals may lead to better clinical outcomes because it maximizes communication, trust, and management opportunities. ${ }^{[53,54]}$

We also looked at other potential determinants of satisfaction (age, sex, education level, annual income, employment status, distance between clinics and residence, first time with a PHCNP, self-perceived health). Other studies also compared patients' satisfaction across similar individual characteristics (age, gender, and educational level) and, as in the present study, no statistically significant associations were found between these factors and patients' satisfaction with PHCNPs. ${ }^{[21,26]}$ Green and Davis however determined that age was the only significant predictor of patients' satisfaction among other individual factors (sex, ethnicity and education), as their study showed that the 18-25 year-old group had lower satisfaction with the nurse practitioner than other age groups. ${ }^{[55]}$ This discrepancy between Green and Davis (2005) results and the present study could be explained by the different study population (i.e., very few 18-25 yearold participants were included in the present investigation). Although other studies have examined the satisfaction of patients meeting with a PHCNP by evaluating other determinants such as waiting time, role clarity, reason for consultation and thoroughness, they did not use multivariate models ${ }^{[10,20,24]}$ which makes the comparison with our study more difficult.

\section{Strengths and limitations}

The present study has several strengths such as a substantially high participation rate which reduces the possibility of selection bias. The participation rate was similar to what was found in a study by Weyer, Cook and Riley (2017) (75.9\%). ${ }^{[54]}$ Moreover, the large sample size of our study helped increase the representativeness of the sample. However, a number of limitations deserve to be mentioned. Although the questionnaire was anonymous and completed after the consultation with a PHCNP, the possibility of social desirability bias in the responses cannot be completely excluded. In addition, a ceiling effect was observed in all measures of satisfaction and appreciation of care provided by PHCNPs. Such deficiency in response variability is problematic and can impact the validity of the satisfaction measures. ${ }^{[56]}$ Also, this situation reduces the statistical power of our analysis. Consequently, it is possible that the lack of statistically significant differences between patients who consulted with a PHCNP before and first timers regarding the different satisfaction outcomes is explained by a Type II error. This type of error could also affect our ability to identify factors associated with patients' satisfaction. In the context of the present study, we can nevertheless conclude that this first exploratory step in investigating patients' perceptions was a useful and successful one. Regarding external validity, we have every reason to believe that the diversity of the present study recruitment sites and similar primary care access challenges between remote regions of the province maximize the chances that our results can be generalized to all remote regions of the province of Quebec.

\section{Conclusions}

Despite the limitations of our study, our results suggest high levels of patients' satisfaction with the care provided by PHCNPs, which potentially reflect high-quality, safe and effective care. ${ }^{[10,24,26]}$ The specific context of PHCNPs integration in the province of Quebec may not necessarily reflect that of other countries. However, the findings of the present investigation demonstrate how their integration is important for patients of remote regions. In addition, the study results provide a compelling argument for collaboration between decision-makers and clinicians to work together to promote and facilitate the integration of PHCNPs. Future research should use longitudinal designs in order to explore how patients' satisfaction levels may change over time (continuity of care) and how different models of PHCNP-physician collaboration can impact this satisfaction.

\section{CONFLICTS OF INTEREST DisClosure}

The authors declare they have no conflicts of interest. 


\section{REFERENCES}

[1] CNPI. Nurse Practitioners: The time is now. A solution to improving access and educing wait times in Canada. Ottawa, Ontario: Canadian Nurse Practitioner Initiative. 2006.

[2] Delamaire ML, Lafortune G. Nurses in advanced roles: A Description and Evaluation of Experiences in 12 Developed Countries OECD Health Working Papers. 2010(54): 106. https://doi.org/10.1 $787 / 5 \mathrm{kmbrcfms} 5 \mathrm{~g} 7-\mathrm{en}$

[3] DiCenso A, Paech G, Corporation I. Report on the Integration of Primary Health Care Nurse Practitioners into the Province of Ontario: Final Report. Toronto, Ontario: Ministry of Health and Long Term Care. 2003.

[4] DiCenso A, Auffrey L, Bryant-Lukosius D, et al. Primary health care nurse practitioners in Canada. Contemp Nurse. 2007; 26(1): 104-15 PMid: 18041990. PMid: 18041990. https://doi.org/10.5172/ conu. 2007.26.1.104

[5] Graydon J, Hendry J. Outpost nursing in Northern Newfoundland. The Canadian Nurse. 1977; 73(8): 34-7.

[6] Kaasalainen S, Martin-Misener R, Kilpatrick K, et al. A historical overview of the development of advanced practice nursing roles in Canada. Nurs Leadersh. 2010; 23: 35-60. PMid: 21478686. https://doi.org/10.12927/cjnl.2010.22268

[7] Miller M, Snyder M, Lindeke L. Nurse Practitioners: Current Status and Future Challenges. Clinical Excellence for Nurse Practitioners. 2005; 9(3): 162-9.

[8] McLaren P. The evolution of the nurse practitioner. Evidence-Based Healthcare and Public Health. 2005; 9: 265-6. https : //doi .org/ $10.1016 / j$. ehbc. 2005.04 .002

[9] Cashin A. The first private practice as a registration authority authorised nurse practitioner in Australia. Australian Journal of Primary Health. 2006; 12(3): 20-5. https : //doi .org/10.1071/PY06041

[10] Griffin M, McDevitt J. An Evaluation of the Quality and Patient Satisfaction With an Advanced Nurse Practitioner Service in the Emergency Department. The Journal for Nurse Practitioners. 2016; 12(8): 553-9. https://doi.org/10.1016/j.nurpra.2016.05.024

[11] Maijala V, Tossavainen K, Turunen H. Identifying nurse practitioners' required case management competencies in health promotion practice in municipal public primary health care. A two-stage modified Delphi study. J Clin Nurs. 2015; 24(17-18): 2554-61. PMid: 25950804. https://doi.org/10.1111/j.1365-2702.2008.02288.x

[12] Bergman K, Perhed U, Eriksson I, et al. Patients' satisfaction with the care offered by advanced practice nurses: a new role in Swedish primary care. International Journal of Nursing Practice. 2013; 19(3) 326-33. PMid: 23730865. https://doi.org/10.1111/ijn.12 072

[13] MSSS. L'infirmière praticienne spécialisée en soins de première ligne: Bilan et orientations de la pratique au Québec [The primary health care nurse practitioner: Assessment and orientations of practice in Quebec]. Québec, Québec: Ministère de la santé et des services sociaux, 2009

[14] OIIQ. Optimiser la contribution des infirmières praticiennes spécialisées pour mieux servir la population québécoise [Optimizing the contribution of specialized nurse practitioners to better serve the Quebec population]. Westmount, Québec: Ordre des infirmières et infirmiers du Québec. 2013.

[15] D'Amour D, Tremblay D, Proulx M. Déploiement de nouveaux rôles infirmiers au Québec et pouvoir médical [Deployment of new nursing roles in Quebec and medical power]. Recherches Sociographiques. 2009; 50(2): 301-20. https ://doi.org/10.7202/038041ar

[16] Hudon R, Martin E, Perreault M. Le pouvoir médical et le défi de la collaboration interprofessionnelle [Medical power and the challenge of interprofessional collaboration. Three scenarios]. Trois cas de figure. Recherches Sociographiques. 2009; 50(2): 321-44. https://doi.org/10.7202/038042ar

[17] OIIQ. Les infirmières praticiennes spécialisées: un rôle à propulser, une intégration à accélerer. Bilan et perspectives de pérennité [Nurse practitioners: A role to propel, an integration to accelerate. Assessment and prospects for sustainability]. Westmount, Québec: Ordre des infirmères et infirmiers du Québec. 2009.

[18] Muntlin A, Gunningberg L, Carlsson M. Patients' perceptions of quality of care at an emergency department and identification of areas for quality improvement. J Clin Nurs. 2006; 15(8): 104556. PMid: 16879549. https ://doi.org/10.1111/j.1365-270 2.2006.01368.x

[19] Crow R, Gage H, Hampson S, et al. The measurement of satisfaction with healthcare: implications for practice from a systematic review of the literature. Health Technol Assess. 2002; 6(32): 1-244. Epub 2003/08/20. PMid: 12925269. https ://doi.org/10.3310/hta6 320

[20] Gagan M, Maybee P. Patient satisfaction with Nurse Practitioner care in primary care settings. Aust J Adv Nurs. 2011; 28(4).

[21] Thrasher C, Purc-Stephenson R. Patient satisfaction with nurse practitioner care in emergency departments in Canada. J Am Acad Nurse Pract. 2008; 20(5): 231-7. PMid: 18460162. https ://doi.org/ $10.1111 / \mathrm{j} .1745-7599.2008 .00312 . \mathrm{x}$

[22] Sun L, Jackson R, Dunne H, et al. Impact of nurse practitioners in primary healthcare fee-for-service practice settings. Healthc Manage Forum. 2015; 28(1): 24-7. PMid: 25838567. https://doi.org/ 10.1177/0840470414551904

[23] Sangster-Gormley E, Griffith J, Schreiber R, et al. Nurse practitioners changing health behaviours: one patient at a time. Nurs Manag (Harrow). 2015; 22(6): 26-31. PMid: 26419574. https: //doi.org/10.7748/nm.22.6.26.e1404

[24] McDevitt J, Melby V. An evaluation of the quality of Emergency Nurse Practitioner services for patients presenting with minor injuries to one rural urgent care centre in the UK: a descriptive study. J Clin Nurs. 2015; 24(3-4): 523-35. PMid: 24891126. https: //doi.org/10.1111/jocn.12639

[25] Jennings N, Lee G, Chao K, et al. A survey of patient satisfaction in a metropolitan Emergency Department: comparing nurse practitioners and emergency physicians. International Journal of Nursing Practice. 2009; 15(3): 213-8. PMid: 19531080. https: //doi.org/10.1111/j.1440-172X.2009.01746.x

[26] Ryan K, Rahman A. Examining factors influencing patient satisfaction with nurse practitioners in rural urgent care centers. $\mathbf{J}$ Am Acad Nurse Pract. 2012; 24(2): 77-81. PMid: 22324862 https://doi.org/10.1111/j.1745-7599.2011.00688.x

[27] Browne A, Tarlier D. Examining the potential of nurse practitioners from a critical social justice perspective. Nurs Inq. 2008; 15(2): 83 93. PMid: 18476851. https://doi.org/10.1111/j.1440-180 $0.2008 .00411 . \mathrm{x}$

[28] Martin-Misener R, Downe-Wamboldta B, Caina E, et al. Cost effectiveness and outcomes of a nurse practitioner-paramedicfamily physician model of care: the Long and Brier Islands Study. Primary Health Care Research and Development. 2009; 10(1): 14 https://doi.org/10.1017/S1463423608000959

[29] Martin-Misener R, Reilly S, Vollman A. Defining the role of primary health care nurse practitioners in rural Nova Scotia. Can J Nurs Res. 2010; 42(2): 30-47. PMid: 20608235.

[30] Quinlan E, Robertson S. The communicative power of nurse practitioners in multidisciplinary primary healthcare teams. Journal of the American Association of Nurse Practitioners. 2013; 25(2): 91102. PMid: 23347245. https ://doi .org/10.1111/j.1745-759 9.2012.00768.x 
[31] Laurant M, Hermens R, Braspenning J, et al. An overview of patients' preference for, and satisfaction with, care provided by general practitioners and nurse practitioners. J Clin Nurs. 2008; 17(20): 26908. PMid: 18647199. https://doi.org/10.1111/j.1365-2702. 2008.02288. $\mathrm{x}$

[32] van der Biezen M, Schoonhoven L, Wijers N, et al. Substitution of general practitioners by nurse practitioners in out-of-hours primary care: a quasi-experimental study. J Adv Nurs. 2016; 72(8): 1813-24. PMid: 26969826. https://doi.org/10.1111/jan.12954

[33] Sangster-Gormley E, Martin-Misener R, Burge F. A case study of nurse practitioner role implementation in primary care: what happens when new roles are introduced? BMC Nursing. 2013; 12(1). PMid: 23343534. https://doi.org/10.1186/1472-6955-12-1

[34] ISQ. Panorama des régions du Québec [Panorama of the regions of Quebec]. Québec, Québec: Institut de la statistique du Québec, 2018.

[35] CISSSAT. Portrait de santé de la population [Population health profile]. Rouyn-Noranda. Québec: Centre intégré de santé et de services sociaux de l'Abitibi-Témiscamingue. 2017.

[36] Touché R. Evaluation of Nurse Practitioner Pilot Projects. London: National Health Service Executive; 1994.

[37] Cole F, Mackey T, Lindenberg J. Quality improvement: psychometric evaluation of patient satisfaction with nurse practitioner care instrument. J Am Acad Nurse Pract. 1999; 11(11): 471-5. PMid: 11000761. https://doi.org/10.1111/j.1745-7599.1999.tb01043.x

[38] Dierick-van Daele A, Metsemakers J, Derckx E, et al. Nurse practitioners substituting for general practitioners: randomized controlled trial. J Adv Nurs. 2009; 65(2): 391-401. PMid: 19191937. https://doi.org/10.1111/j.1365-2648.2008.04888.x

[39] Van Soeren M, Hurlock-Chorostecki C, Goodwin S, et al. The primary healthcare nurse practitioner in Ontario: a workforce study. Nurs Leadersh (Tor Ont). 2009; 22(2): 58-72. Epub 2009/06/13. PMid: 19521161. https://doi.org/10.12927/cjnl.2009.2 0798

[40] Van Soeren M, Micevski V. Success indicators and barriers to acute nurse practitioner role implementation in four Ontario hospitals. AACN clinical issues. 2001; 12(3): 424-37. PMid: 11759360. https ://doi.org/10.1097/00044067-200108000-00010

[41] Benkert R, Hollie B, Nordstrom C, et al. Trust, mistrust, racial identity and patient satisfaction in urban African American primary care patients of nurse practitioners. Journal of Nursing Scholarship. 2009; 41(2): 211-9. PMid: 19538706. https://doi.org/10.1111/j. 1547-5069.2009.01273.x

[42] DiCenso A, Bourgeault I, Abelson J, et al. Utilization of nurse practitioners to increase patient access to primary healthcare in Canadathinking outside the box. Nurs Leadersh (Tor Ont). 2010; 23(2010): 239-59. PMid: 21478696. https://doi.org/10.12927/cjnl. 2010.22281

[43] Agosta L. Patient satisfaction with nurse practitioner-delivered primary healthcare services. J Am Acad Nurse Pract. 2009; 21(11): 610-7. PMid: 19900223 . https://doi.org/10.1111/j.1745-7 $599.2009 .00449 . x$
[44] Budzi D, Lurie S, Singh K, et al. Veterans' perceptions of care by nurse practitioners, physician assistants, and physicians: a comparison from satisfaction surveys. J Am Acad Nurse Pract. 2010; 22(3): 170-6. PMid: 20236402. https://doi.org/10.1111/j.1745-7 $599.2010 .00489 . \mathrm{x}$

[45] Pearson S, Raeke L. Patients' trust in physicians: many theories, few measures, and little data. J Gen Intern Med. 2000; 15(7): 50913. PMid: 10940139. https://doi.org/10.1046/j.1525-149 7.2000.11002.x

[46] van den Brink-Muinen A, Rijken P. Does trust in health care influence the use of complementary and alternative medicine by chronically ill people? BMC Public Health. 2006; 6: 188. PMid: 16848897. https://doi.org/10.1186/1471-2458-6-188

[47] Hayes E. Nurse practitioners and managed care: patient satisfaction and intention to adhere to nurse practitioner plan of care. J Am Acad Nurse Pract. 2007; 19(8): 418-26. PMid: 17655571 https://doi.org/10.1111/j.1745-7599.2007.00245.x

[48] Statistique Canada. Enquête sur la santé dans les collectivités canadiennes - Composante annuelle (ESCC) 2013-2014 [Canadian Community Health Survey - Annual component (CCHS) 2013-2014]. Ottawa, Ontario: Statistique Canada. 2015.

[49] Kinnersley P, Stott N, Peters T, et al. A comparison of methods for measuring patient satisfaction with consultations in primary care. Fam Pract. 1996; 13(1): 41-51. Epub 1996/02/01. PMid: 8671103. https://doi.org/10.1093/fampra/13.1.41

[50] Williams A, Jones M. Patients' assessments of consulting a nurse practitioner: the time factor. J Adv Nurs. 2006; 53(2): 188-95. PMid: 16422717. https://doi.org/10.1111/j.1365-2648.2006.0 $3714 . \mathrm{x}$

[51] Seale C, Anderson E, Kinnersley P. Comparison of GP and nurse practitioner consultations: an observational study. The British Journal of General Practice. 2005; 55(521): 938-43. PMid: 16378563.

[52] Gilbert D, Hayes E. Communication and outcomes of visits between older patients and nurse practitioners. Nurs Res. 2009; 58(4): 28393. PMid: 19609180. https://doi.org/10.1097/NNR.0b013e $3181 \mathrm{ac} 1413$

[53] Chen L, Farwell W, Jha A. Primary care visit duration and quality: does good care take longer? Arch Intern Med. 2009; 169(20): 186672. PMid: 19901138. https://doi.org/10.1001/archintern med.2009. 341

[54] Weyer S, Cook M, Riley L. The Direct Observation of Nurse Practitioner Care study: An overview of the NP/patient visit. Journal of the American Association of Nurse Practitioners. 2017; 29(1): 46-57. PMid: 27973706. https ://doi .org/10.1002/2327-692 4.12434

[55] Green A, Davis S. Toward a predictive model of patient satisfaction with nurse practitioner care. J Am Acad Nurse Pract. 2005; 17(4): 139-48. PMid: 15819639. https://doi.org/10.1111/j.1041 $-2972.2005 .0022 . x$

[56] Masino C, Lam T. Choice of rating scale labels: implication for minimizing patient satisfaction response ceiling effect in telemedicine surveys. Telemedicine Journal and E-health. 2014; 20(12): 1150-5. PMid: 25379838. https ://doi .org/10.1089/tmj . 2013.0350 